\title{
NO EYE PAD FOR CORNEAL ABRASION
}

\author{
J. N. P. KIRKPATRICK, H. B. HOH and S. D. COOK \\ Bristol
}

\begin{abstract}
SUMMARY
We have carried out a randomised clinical trial to assess the healing rate and level of discomfort experienced in two groups of patients with simple traumatic corneal abrasions. Patients treated with antibiotic ointment and mydriatic alone have a significantly improved healing rate compared with those treated with antibiotic ointment, mydriatic and a double eye pad with bandage $(0.05>p>0.02)$. There was no significant difference in the level of discomfort experienced by the two groups.
\end{abstract}

Traumatic corneal abrasion is a common presenting problem at an eye casualty department. This condition has been reported to be responsible for more than $10 \%$ of new patient attendance in some units. ${ }^{1}$ Although short lasting a corneal abrasion gives rise to marked discomfort and visual disability. Established treatment is to apply a topical antibiotic (with or without topical mydriatic) and then a firm eye pad. ${ }^{2}$ Eye padding is felt to offer a stable corneal environment for epithelial healing, but there are some theoretical and practical disadvantages. A dressing may reduce corneal oxygenation and increase corneal temperature which could slow epithelial healing and predispose to secondary infection. Furthermore a considerable number of patients complain of marked discomfort whilst wearing an eye pad which is relieved by its removal.

The aim of this study was to assess the rate of recovery and level of patient discomfort when eye pads were omitted from the treatment regime.

\section{MATERIALS AND METHODS}

Between 1 August 1991 and 31 December 1991 patients seen at Bristol Eye Hospital casualty department suffering from a traumatic corneal abrasion of less than 24 hours' duration were entered into the trial. Ethical committee approval was granted for the trial and all patients gave informed consent. Forty-four patients were entered into a

From: Bristol Eye Hospital, Lower Maudlin Street, Bristol BS1 2LX, UK.

Correspondence to: J. N. P. Kirkpatrick, FCOphth, Ophthalmology Department, Aberdeen Royal Infirmary, Foresterhill, Aberdeen AB9 2ZD, UK. randomised controlled trial after fulfilling the following criteria: the patient was over 18 years of age, there was no previous history of eye trauma or disease in the affected eye, the injury was a simple corneal abrasion with no other signs of significant ocular trauma or presence of foreign body, and no treatment had been given prior to inclusion in the trial. Abrasion size was measured by comparison of maximum and minimum dimensions with the slit beam of a Haag-Streit 900 slit lamp and then the approximate area was calculated. Patients were assigned to one of two treatment groups. Group A received oc. chloramphenicol, gutt. homatropine $2 \%$ and a double eye pad with bandage. Group B received oc. chloramphenicol q.d.s. and gutt. homatropine $2 \%$ once daily with no eye pad. Patients were permitted to take simple analgesics such as aspirin and paracetamol for pain relief. All patients were reviewed at 24 hour intervals to monitor healing and the subjective level of discomfort, which was assessed on a visual analogue scale. The scale ranged from 0 to 100 , with 0 representing no pain and 100 representing severe pain.

Abrasion healing was considered to be complete when regenerated epithelial edges were apposed with only minor punctate staining after fluorescein installation (gutt. benoxinate $0.5 \%$ and fluorescein-impregnated strip). After complete healing all patients were instructed to use oc. chloramphenicol q.d.s. for 3 days and to return for final assessment at 7 days. Any subsequent casualty department attendance for complications was recorded in the follow-up period (2-7 months).

\section{RESULTS}

Individual patient details are recorded in Tables I and II. Statistical analyses of the two groups are shown in Table III. The two groups do not differ significantly in terms of patient age, sex, time elapsed before presentation, mode of injury or size of corneal abrasion. Parametric tests were used (Student's $t$-test) except for the comparison of abrasion size; in this there were two results from each group which were considerably larger than the remainder and so a non-parametric test was applied (Mann-Whitney $U$-test).

There is a significantly improved rate of epithelial heal- 
Table I. Patient data: group A (with eye pad)

\begin{tabular}{|c|c|c|c|c|c|c|c|c|c|c|}
\hline $\begin{array}{l}\text { Patient } \\
\text { no. }\end{array}$ & $\begin{array}{l}\text { Age } \\
(y r)\end{array}$ & Sex & $\begin{array}{l}\text { Mode of } \\
\text { injury }\end{array}$ & $\begin{array}{l}\text { Time since } \\
\text { injury } \\
\text { (hours) }\end{array}$ & $\begin{array}{l}\text { Abrasion } \\
\text { size } \\
\left(\mathrm{mm}^{2}\right)\end{array}$ & $\begin{array}{l}\text { Difference } \\
\text { in pain score } \\
\text { at } 24 \text { hours }\end{array}$ & $\begin{array}{c}\text { Time to } \\
\text { heal } \\
\text { (days) }\end{array}$ & $\begin{array}{l}\text { No. pads } \\
\text { applied }\end{array}$ & $\begin{array}{l}\text { No. pads } \\
\text { removed }\end{array}$ & Comments \\
\hline 1 & 57 & $\mathbf{M}$ & Twig & 20 & 8 & -9 & 2 & 2 & $2 \mathrm{~F}$ & \\
\hline 3 & 30 & $\mathrm{M}$ & Fingernail & 21 & 14 & -28 & - & 1 & $1 \mathrm{~F}$ & DNA day 2 \\
\hline 6 & 29 & $\mathrm{~F}$ & Twig & 5 & 3 & +9 & 3 & 3 & 0 & \\
\hline 8 & 20 & M & Twig & 16 & 2 & - & - & - & - & DNA day 1 \\
\hline 10 & 25 & $\mathbf{M}$ & Tool & 2 & 0.4 & -13 & 1 & 1 & $1 \mathrm{P}$ & \\
\hline 14 & 63 & $\mathbf{M}$ & Plastic & 24 . & 1 & -31 & 1 & 1 & $1 \mathrm{~F}$ & \\
\hline 15 & 29 & M & Nail & 6 & 3 & +5 & 3 & 3 & $2 \mathrm{P}$ & \\
\hline 16 & 29 & $\mathrm{~F}$ & Dog & 5 & 2 & -49 & 2 & 2 & 0 & \\
\hline 20 & 36 & $\mathrm{M}$ & Fingernail & 14 & 2 & -41 & 2 & 2 & $1 \mathrm{~F}$ & \\
\hline 21 & 45 & $\mathbf{M}$ & Fingernail & 4 & 1 & -4 & 2 & 2 & $2(1 \mathrm{~F}, 1 \mathrm{P})$ & \\
\hline 23 & 28 & M & 'Fingernail & 19 & 6 & -39 & 2 & 2 & $2(1 \mathrm{~F}, 1 \mathrm{P})$ & \\
\hline 24 & 30 & $\mathrm{~F}$ & Fingernail & 6 & 2 & +4 & 3 & 3 & $2(1 \mathrm{~F}, 1 \mathrm{P})$ & \\
\hline 26 & 42 & $\mathrm{M}$ & Fingernail & 12 & 8 & +1 & 3 & 3 & 0 & \\
\hline 30 & 32 & $\mathbf{M}$ & Twig & 16 & 1 & -51 & 2 & 2 & 0 & \\
\hline 32 & 38 & M & Stone & 8 & 1 & -35 & 1 & 1 & 0 & \\
\hline 34 & 46 & M & Cat & 18 & 7 & -31 & 2 & 2 & $2(1 \mathrm{~F}, 1 \mathrm{P})$ & \\
\hline 36 & 29 & $\mathrm{~F}$ & Fingernail & 2 & 2 & - & 2 & 2 & 0 & Pain score not recorded \\
\hline 40 & 49 & M & Twig & 16 & 3 & -38 & 1 & 1 & 0 & \\
\hline 43 & 38 & M & Fingernail & 24 & 16 & - & 一 & - & - & DNA day 1 \\
\hline 44 & 32 & $\mathbf{M}$ & Fingernail & 20 & 1 & -5 & 2 & 2 & $1 \mathrm{~F}$ & \\
\hline
\end{tabular}

Total no. $=20$ ( 3 patients excluded).

F, fell off; P, painful; DNA, did not attend.

ing in those patients not treated with an eye pad as shown using a two-tailed Student's $t$-test $(p=0.044)$ and also using a chi-squared analysis for linear association $(p=0.046)$ (Mantel Haenszel test). This is shown in Fig. 1. The pain score after 24 hours was taken as the difference between the scores at 24 hours and on admission to the trial. As shown in Fig. 2 there is no significant difference between the two groups in this respect.
In group A (eye pad) 3 patients (nos. 3, 8 and 43) defaulted from the trial and no assumptions can be made as to their healing rate. Patient 3 attended for the first follow-up visit and so a pain score was recorded. The pain score for patient 36 was omitted in error by the examining doctor. In this group a total of 35 eye pads with bandages were applied and of these $17(48.6 \%)$ were not in situ when the patient was reviewed 24 hours later. Ten patients

Table II. Patient data: group B (no eye pad)

\begin{tabular}{|c|c|c|c|c|c|c|c|c|}
\hline $\begin{array}{l}\text { Patient } \\
\text { no. }\end{array}$ & $\begin{array}{l}\text { Age } \\
(\mathrm{yr})\end{array}$ & Sex & $\begin{array}{l}\text { Mode of } \\
\text { injury }\end{array}$ & $\begin{array}{c}\text { Time since } \\
\text { injury } \\
\text { (hours) }\end{array}$ & $\begin{array}{l}\text { Abrasion } \\
\text { size } \\
\left(\mathrm{mm}^{2}\right)\end{array}$ & $\begin{array}{l}\text { Difference } \\
\text { in pain score } \\
\text { at } 24 \text { hours }\end{array}$ & $\begin{array}{c}\text { Time to } \\
\text { heal (days) }\end{array}$ & Comments \\
\hline 2 & 18 & $\mathrm{~F}$ & Wire & 6 & 3 & -19 & 1 & \\
\hline 4 & 51 & M & Paper & 1 & 5 & - & - & DNA day 1 \\
\hline 5 & 52 & $\mathrm{~F}$ & Leaf & 14 & 5 & -24 & 1 & Recurrent erosion $\times 2$ \\
\hline 7 & 28 & $\mathrm{~F}$ & Fingernail & 5 & 6 & -55 & 1 & \\
\hline 9 & 29 & $\mathrm{~F}$ & Fingernail & 20 & 39 & +3 & 3 & \\
\hline 11 & 31 & $\mathrm{~F}$ & Twig & 20 & 1 & +3 & 1 & \\
\hline 12 & 34 & $\mathrm{~F}$ & Leaf & 12 & 1 & -19 & 2 & \\
\hline 13 & 24 & M & Leaf & 18 & 1 & -9 & 2 & \\
\hline 17 & 28 & $\mathbf{M}$ & Bird & 4 & 0.3 & -59 & 1 & \\
\hline 18 & 29 & $\mathrm{~F}$ & Glass & 3 & 1 & +10 & 2 & \\
\hline 19 & 55 & $\mathrm{~F}$ & Paper & 24 & 0.3 & -19 & 2 & \\
\hline 22 & 64 & M & Fingernail & 10 & 3 & -12 & 2 & \\
\hline 25 & 29 & $\mathbf{M}$ & Wire & 5 & 3 & -49 & 1 & \\
\hline 27 & 39 & $\mathbf{M}$ & Twig & 12 & 1 & - & - & $\begin{array}{l}\text { ? Dendritic ulcer at day } 1 \text { : } \\
\text { withdrawn }\end{array}$ \\
\hline 28 & 47 & $\mathrm{~F}$ & Twig & 16 & 2 & -6 & 2 & \\
\hline 29 & 27 & $\mathrm{~F}$ & Fingernail & 10 & 0.5 & -32 & 1 & \\
\hline 31 & 43 & $\mathbf{M}$ & Wire & 5 & 2 & -22 & 2 & \\
\hline 33 & 32 & $\mathrm{~F}$ & Nail & 3 & 14 & -27 & 2 & \\
\hline 35 & 27 & $\mathrm{~F}$ & Toy & 4 & 6 & -77 & 1 & \\
\hline 37 & 26 & M & Fingernail & 4 & 5 & -26 & 1 & \\
\hline 38 & 32 & $\mathrm{~F}$ & Fingernail & 15 & 0.5 & -69 & 1 & \\
\hline 39 & 39 & $\mathrm{~F}$ & Paper & 3 & 2 & - & - & $\begin{array}{l}\text { Re-attended at } 12 \text { hours, } \\
\text { pad applied: withdrawn }\end{array}$ \\
\hline 41 & 32 & M & Fingernail & 4 & 2 & -44 & 2 & \\
\hline 42 & 23 & M & Fingernail & 20 & 7 & $\ldots$ & - & DNA day 1 \\
\hline
\end{tabular}

Total no. $=24$ (4 patients excluded)

DNA, did not attend. 
Table III. Statistical analysis of data

\begin{tabular}{|c|c|c|c|c|c|c|}
\hline & \multicolumn{2}{|c|}{ Group A } & \multicolumn{2}{|c|}{ Group B } & \multirow[b]{2}{*}{ Statistical test used } & \multirow[b]{2}{*}{$p$ value } \\
\hline & Mean & SD & Mean & SD & & \\
\hline Age (yr) & 36.3 & 11.0 & 35.0 & 11.5 & Student's $t$ & 0.68 \\
\hline Time since injury (hours) & 12.9 & 7.50 & 10.5 & 6.78 & Student's $t$ & 0.28 \\
\hline Abrasion size $\left(\mathrm{mm}^{2}\right)$ & 4.17 & 4.41 & 4.61 & 7.95 & Mann-Whitney $U$ & 0.28 \\
\hline Time to heal (days) & 2.00 & 0.71 & 1.55 & 0.61 & $\begin{array}{l}\text { Student's } t \\
\text { chi-squared }\end{array}$ & $\begin{array}{l}0.044 * \\
0.046 *\end{array}$ \\
\hline Pain score at 24 hours & -20.8 & 20.3 & -27.6 & 24.2 & Student's $t$ & 0.37 \\
\hline
\end{tabular}

*Significant.

(28.6\%) reported that their eye pads fell off whilst asleep while a further $7(20 \%)$ patients stated that the pad had been too uncomfortable to wear.

In group B (no eye pad) 4 patients did not complete the study. Two patients (nos. 4 and 42) failed to attend for follow-up while the eye of another patient (no. 27) was thought to have the appearance of a dendritic ulcer on day 1 and was withdrawn. A further patient (no. 39) reattended the casualty department at night after inclusion into the study complaining of ocular pain, and an eye pad was applied by nursing staff unbeknown to the investigators. This patient made an uneventful recovery but the data were not used for analysis.

One patient in group B (no eye pad) had two episodes of recurrent erosion in the follow-up period of 27 weeks which required further treatment. No other complications were apparent in either group.

\section{DISCUSSION}

Corneal epithelial wounds heal by a process of cell migration and cell proliferation. ${ }^{3,4}$ For abrasions which involve less than $60 \%$ of the total corneal surface area, as in this study, there is an exponential decrease in wound size with time and one would expect such wounds to heal in 1-4 days. ${ }^{5}$ With both methods of treatment all abrasions in this study healed within 3 days.

Our study has shown a significant improvement in the rate of healing of traumatic corneal abrasion in those patients treated with antibiotic ointment and mydriatic alone compared with the use of antibiotic ointment, mydriatic and an occlusive eye pad and bandage (see

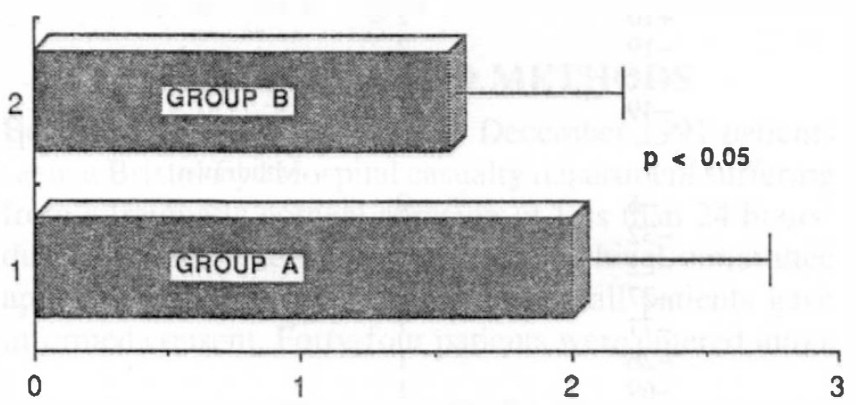

DAYS TO HEAL

Fig. 1. Bar chart to show the number of days to heal for groups $A$ (eye pad) and $B$ (no eye pad). The standard deviation of the mean is shown as an error bar. Note $\mathrm{p}<0.05$.
Table III and Fig. 1). Factors which are regarded as important in the promotion of rapid corneal healing after abrasion include presence of an intact basement membrane, maintenance of adequate corneal hydration and protection from secondary infection. ${ }^{6}$ The role of blinking as a factor which retards healing is questioned by our study. Our results indicate that the prevention of blinking by use of an eye pad and bandage is not necessary for rapid healing. The suggestion that blinking may hinder epithelial attachment to the underlying basement membrane does not appear to be significant in traumatic abrasions of this size. Conversely a firm eye pad may produce an adverse corneal environment with pressure applied to the regenerating epithelium as well as a reduction in the level of oxygenation. With the eye open the partial pressure of oxygen in the corneal epithelium is approximately $155 \mathrm{mmHg}$; this falls to $55 \mathrm{mmHg}$ with eye closure. ${ }^{7}$ This lower oxygen level may retard epithelial migration and proliferation.

Whether the application of an eye pad may increase the risk of infection is unclear. This risk is small and it has not been demonstrated clinically. In a study of patients undergoing cataract surgery with or without eye pads postoperatively there was no significant difference in the bacterial flora grown from lid and conjunctival swabs between the two groups. ${ }^{8}$

The use of an ophthalmic ointment in preference to eye drops for traumatic abrasion permits a longer contact time between the antibiotic and the ocular surface. The ointment also acts as a lubricant between the upper lid and the abraded surface. A suggestion that ointment might

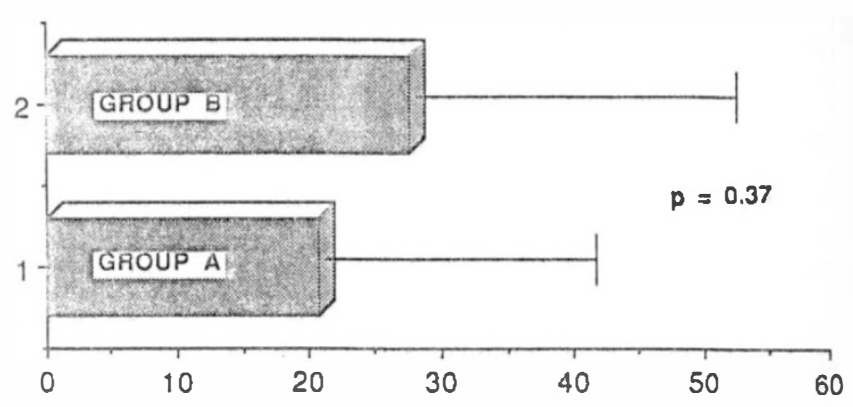

MEAN REDUCTION IN PAIN SCORE AT 24 HOURS (\%)

Fig. 2. Bar chart to show the difference in pain score between groups A (eye pad) and B (no eye pad) at 24 hours after injury. The standard deviation of the mean for each group is shown as an error bar. $\mathrm{p}=0.37$. 
become trapped beneath the healing epithelium, thus inhibiting repair, has been disproved. ${ }^{9}$

The change in pain score after 24 hours was not significantly different between the two groups although the mean reduction in pain was slightly greater for the nonpadded group (see Table III and Fig. 2). A larger study would be required to assess this factor. Analgesics taken by some patients may slightly affect the degree of discomfort felt. It can be stated that there is a marked reduction in pain score in those patients who were healed at 24 hours (mean $=39.4$ ), which implies that more rapid abrasion healing should reduce the period of discomfort.

Wearing an eye pad caused discomfort to $20 \%$ of patients in group A sufficient to cause them to remove the pad. A further $28 \%$ of patients preferred not to replace eye pads reported to have fallen off, even though they had been asked to keep the pad on for the 24 hour period. It is interesting to consider why only a proportion of patients found that their eye pads were too uncomfortable to keep in place. It may be that the pressure of a firm eye pad on the abraded surface via the closed eyelid is intolerable, but equally a quite different argument could be suggested whereby an eye pad is too loose and allows lid opening beneath it. In this study a double eye pad and bandage dressing was used to try to minimise the chance of the latter event, although a technique of taping the eyelids closed could also be employed (provided that tears and extruded ointment did not interfere with skin adhesion).

The complication rate for the two groups was similar, with only 1 patient in group B (no eye pad) suffering from the recurrent erosion syndrome in a 6 month follow-up period. Patient no. 27 appeared to have herpes simplex keratitis on the first follow-up visit and it seems that this patient was erroneously included in the trial.

This study has certain limitations which should be highlighted. The number of patients in each group, although small, was sufficient to demonstrate a healing rate in unpadded patients that was just significantly better than those treated with eye pads. An increase in patient numbers might show greater significance. Similarly with increased patient numbers a difference in patient comfort between the two groups might be demonstrated. The corneal abrasions included were generally small in area, but we feel that this is representative of the total population of corneal injuries seen in this department and thus all measurable abrasions were included. A further criticism is that the observers were aware which treatment group patients fell into and thus it is possible that bias may have been introduced.

An alternative treatment for traumatic corneal abrasion which has been suggested by Acheson et al. is the use of soft bandage contact lenses. ${ }^{10}$ Whilst this appears to result in a more rapid resolution of the corneal injury and a reduction in the level of patient discomfort there are some disadvantages to this method in terms of potential corneal infection, ${ }^{11}$ the need for specialist supervision and cost of treatment. In Acheson's study 1 patient defaulted from follow up with a bandage lens in situ which might have caused considerable problems. This method of treatment is unlikely to gain widespread acceptance.

No attention has been given here to the use of eye pads for treatment of recurrent corneal erosions or persistent epithelial defects secondary to other corneal diseases. Omission of eye pads in these patients may be detrimental but is beyond the scope of this study. However, the results suggest that it does seem reasonable to treat primary corneal abrasions in the first instance with antibiotic ointment and mydriatic and no eye pad, and that this will lead to rapid corneal healing within $1-4$ days.

We wish to thank the nursing staff of Bristol Eye Hospital Casualty Department for their help and co-operation and also Mrs. D. Russell, Department of Public Health, University of Aberdeen, for her assistance with the statistical data in this paper.

Key words: Cornea, Corneal epithelium, Injury, Pain score, Treatment, Wound healing.

\section{REFERENCES}

1. Chiapella AP, Rosenthal AR. One year in an eye casualty. $\mathrm{Br}$ J Ophthalmol 1985;69:865-70.

2. Duke-Elder WS. System of ophthalmology. Vol. VI. London: Kimpton, 1952:5993-7.

3. Khodadoust AA, Silverstein Am, Kenyon KR, Dowling JE. Adhesion of regenerating corneal epithelium. Am J Ophthalmol 1968;65:339-48.

4. Hanna C. Proliferation and migration of epithelial cells during corneal wound repair in the rabbit and the rat. Am J Ophthalmol 1966;61:55.

5. Dua HS, Forrester JV. The corneoscleral limbus in human corneal epithelial wound healing. Am J Ophthalmol 1990; 110:646-56.

6. Smolin G, Thoft RA. The cornea: scientific foundations and clinical practice. Boston: Little, Brown, 1983:414.

7. Weissman BA. Predicted changes in tear layer oxygen. Int Contact Lens Clin 1980;5:41-4.

8. Laws DE, Watts MT, Kirkby GR, Lawson J. Is padding necessary after cataract extraction? Br J Ophthalmol 1989; 73:699-701.

9. Fraunfelder FT, Hanna C, Cable M, Hardberger RE. Entrapment of ophthalmic ointment in the cornea. Am J Ophthalmol 1973;76:475-84.

10. Acheson JF, Joseph J, Spalton DJ. Use of soft contact lenses in an eye casualty department for the primary treatment of traumatic corneal abrasions. Br J Ophthalmol 1987;71: 285-9.

11. Editorial. Traumatic corneal abrasion. Lancet 1987;2:1250. 